\title{
Inter-regional beta-diversity patterns of the woody flora of Greece
}

\author{
Fotios Xystrakis ${ }^{1 \S}$, Dimitrios Mitsios-Antonakos², Eleni Eleftheriadou², \\ Panayotis Dimopoulos ${ }^{3}$, Konstantinos Theodoropoulos ${ }^{2}$
}

Xystrakis F., Mitsios-Antonakos D., Eleftheriadou E., Dimopoulos P., Theodoropoulos K., 2019. Inter-regional beta-diversity patterns of the woody flora of Greece. Ann. For. Res. 62(1):_-_.

Abstract. This study aimed to estimate and explain the compositional differentiation and observed beta-diversity (partitioned as turnover and nestedness) patterns of woody species in Greece. Specifically, the 13 phytogeographical regions of Greece were compared at three taxonomic levels: family, genus, and (sub-) species. In Greece, 565 woody taxa have been identified, which are classified into 224 genera and 85 families. Phytogeographical regions were grouped according to their similarity in floristic composition using cluster analysis. Dominant beta diversity gradients were detected using Mantel directional correlation tests applied at the three taxonomic levels. The 13 phytogeographical regions formed three groups; namely, the northern, central, and southern (Aegean Islands) regions. The taxonomic variation among the phytogeographical regions at the species level was related to a gradient of richness of widespread taxa and Balkan endemic taxa. Analysis at the taxonomic levels of species and genus produced similar results, yet, at the family level, floristic differences were less pronounced, with phytogeographical regions being aggregated in two groups: the southernmost island regions versus all other regions. Beta diversity was higher along a northwestern to southeastern gradient, which was related to a dominant climatic gradient throughout Greece. The partitioning of beta diversity between neighboring phytogeographical regions showed that species turnover was the dominant component; yet, some phytogeographical regions (e.g., Kiklades) were characterized by high nestedness. In conclusion, analysis of woody taxa provides different insights regarding the floristic variation of phytogeographical regions.

Keywords: compositional nestedness, directional Mantel correlation, phytogeographical region, species/genus/family turnover, taxonomic richness gradient

Authors. 'Forest Research Institute, Hellenic Agricultural Organization "Demeter", Greece ${ }^{2}$ Department of Forestry and Natural Environment, Aristotle University of Thessaloniki, Greece ${ }^{3}$ Department of Biology, University of Patras, Greece.

§Corresponding author: fotios.xystrakis@fri.gr 
Manuscript received January 4, 2019; revised February 20, 2019; accepted March 24, 2019; online first April 4, 2019.

\section{Introduction}

Altitudinal and latitudinal gradients in species richness and composition, along with the factors controlling such gradients, are the subject of long-standing debates in vegetation ecology (O’Brien 1993, Whittaker et al. 2001). Beta diversity ( $\beta$-diversity) and its ecological gradients are frequently used to understand ecosystem functioning (Legendre et al. 2005). In comparison, the richness of vascular plants is often associated with high values of biodiversity and productivity (Gillman et al. 2015). Thus, a complete inventory of the vascular plants in a region, combined with detailed information on their spatial occurrence, allows various hypotheses to be tested and analyses to be performed that provide insights about basic and applied research questions (Willig et al. 2003, Mittelbach et al. 2007, Kreft \& Jetz 2010, Kraft et al. 2011, Zhang et al. 2016). Furthermore, through distinguishing the two components of $\beta$-diversity, turnover and nestedness (Baselga 2010), our understanding of differences between environmental filtering and ordered extinction vs. colonization dynamics may be facilitated (Janne et al. 2018). High values of nestedness indicate that the sample/region under consideration might represent a subset of adjacent, species rich samples/regions. In comparison, high turnover rates indicate strong changes to floristic composition (Baselga 2010).

Many factors contribute in shaping diversity gradients, with many studies investigating such gradients at various spatial scales to test ecological hypotheses (Willig et al. 2003, Mittelbach et al. 2007) in the northern (Qian \& Ricklefs 2007) and southern (Bannister et al. 2012) hemisphere. Environmental dissimilarity (distance in environmental and geographical space) is the main cause for turnover in plant assemblages (Buckley \& Jetz 2008), with climate variation probably explaining most of the observed variation in species space (Qian \& Ricklefs 2007, Qian et al. 2008, Soininen 2010), at least when respective spatial scales are considered (Pausas \& Austin 2001). Yet, debate remains about the exact causal mechanisms of observed diversity gradients, and whether such gradients are the effect of a single acting factor or a combination of factors (Hillebrand 2004). Aside from climate, other factors that act at different spatial scales, including landscape diversity (Pausas \& Austin 2001), disturbance regimes, variation in the availability of resources (Cowling et al. 1996, Whittaker et al. 2001), or history (Field 2002), could also shape plant distribution patterns. The relative importance of explanatory parameters depends on the scale of sampling and remains poorly understood (Qian \& Ricklefs 2007).

By delineating phytogeographical regions, it is possible to: (a) classify the occurrence of organisms into ecologically meaningful spatial units, instead of using politically-driven limits, and (b) enhance conservation planning (González-Orozco et al. 2014, Socolar et al. 2016). Strid (1986) proposed dividing continental Greece and Crete into eight phytogeographical regions based on the floristic elements of their mountains, as well as some important geographical barriers. Later, Strid \& Tan (1997) adjusted these eight phytogeographical regions into thirteen (13) phytogeographical regions. Different attempts have been made to redraw the phytogeographical regions of Greece based on numerical analyses of floristic inventories (Kougioumoutzis et al. 2014, Kougioumoutzis et al. 2017); however, to date, the phytogeographical classification of Greece by Strid \& Tan (1997) is the only known complete classification that is commonly adopted in studies (e.g. Panitsa 
\& Kontopanou (2017)). This regional classification of Greece was mostly based on empirical knowledge, with analyses of floristic composition being rather descriptive and lacking statistical support. Diversity patterns have been analyzed to delineate phytogeographical regions (González-Orozco et al. 2014), and could be used to test the validity of existing delineations. The latest advances in inventorying vascular flora in Greece created a premise for comprehensively analyzing $\beta$-diversity patterns at the level of the phytogeographical regions in Greece.

This study focused on analyzing the diversity gradients of woody taxa. This approach was used because woody taxa represent important surrogates for both biomass and biodiversity (Latini et al. 2017), as their occurrence correlates well with the total number of plant species at intermediate spatial scales (Abbate et al. 2012, Abbate et al. 2015). Woody plants dominate the landscape because they are floristic components of the final stages of succession (Glavac 1996) and strongly influence the structure of vegetation communities (Roma-Marzio et al. 2015). Woody plants are useful for assessing how environmental drivers shape spatial variation (Qian 2013), because their reproductive organs are directly exposed to the environment (and, hence, weather). Furthermore, land-use history affects the distribution patterns of this group (Kobayashi \& Koike 2010). The composition of woody taxa can be used to delineate phytogeographical regions (Latini et al. 2017), providing a complementary perspective to delineations based on total floristic composition. Similarly, the use of higher taxonomic levels (genera and families) for the investigation of diversity patterns is desirable because, on one hand, the diversity at higher taxonomic levels is highly correlated with the diversity at species level (Latini et al. 2017) and successfully describes the compositional turnover, while on the other hand, it requires less effort for the information to be obtained (Landeiro et al. 2012, Latini et al.
2017).

This study aimed to analyze the compositional differentiation of woody species among the phytogeographical regions of Greece at various taxonomic levels. We aimed to develop a robust analysis and interpretation of the observed patterns of floristic variation and its decomposition. We also tested the validity of describing floristic patterns and similarities between phytogeographical regions by using broader taxonomic levels.

\section{Materials and methods}

\section{Species inventory}

The most recent inventory of the woody taxa of Greece in each phytogeographical region (Figure 1) was exported using the floristic inventory from Dimopoulos et al. (2013) and Dimopoulos et al. (2016) (see also http://portal. cybertaxonomy.org/flora-greece/). Currently, in Greece, we apply the following concept for taxon/taxa at the species level after Dimopoulos et al. (2013): taxa are defined species containing one subspecies and species that have no subspecies, i.e., when a species has subspecies only its subspecies are counted. Hence, in the case of a species with no subspecies, we have a single taxon; in the case of a species with one subspecies in Greece we have one taxon, not two; and in the case of a species with two or more subspecies in Greece, we have two or more taxa. We defined woody taxa as all phanerophytes and all woody chamaephytes (small shrubs, dwarf shrubs). Because only a portion of chamaephytes are woody plants, we searched related floras (Davis 1965-2000, Tutin et al. 1968-1980, Pignatti 1982, Tutin et al. 1993, Jahn \& Schönfelder 1995, Strid \& Tan 1997, Strid \& Tan 2002, Strid 2016) to confirm their life-form and decide their inclusion in the inventory of woody taxa of Greece. The chorological spectrum of woody flora for each phytogeographical region was assessed using 


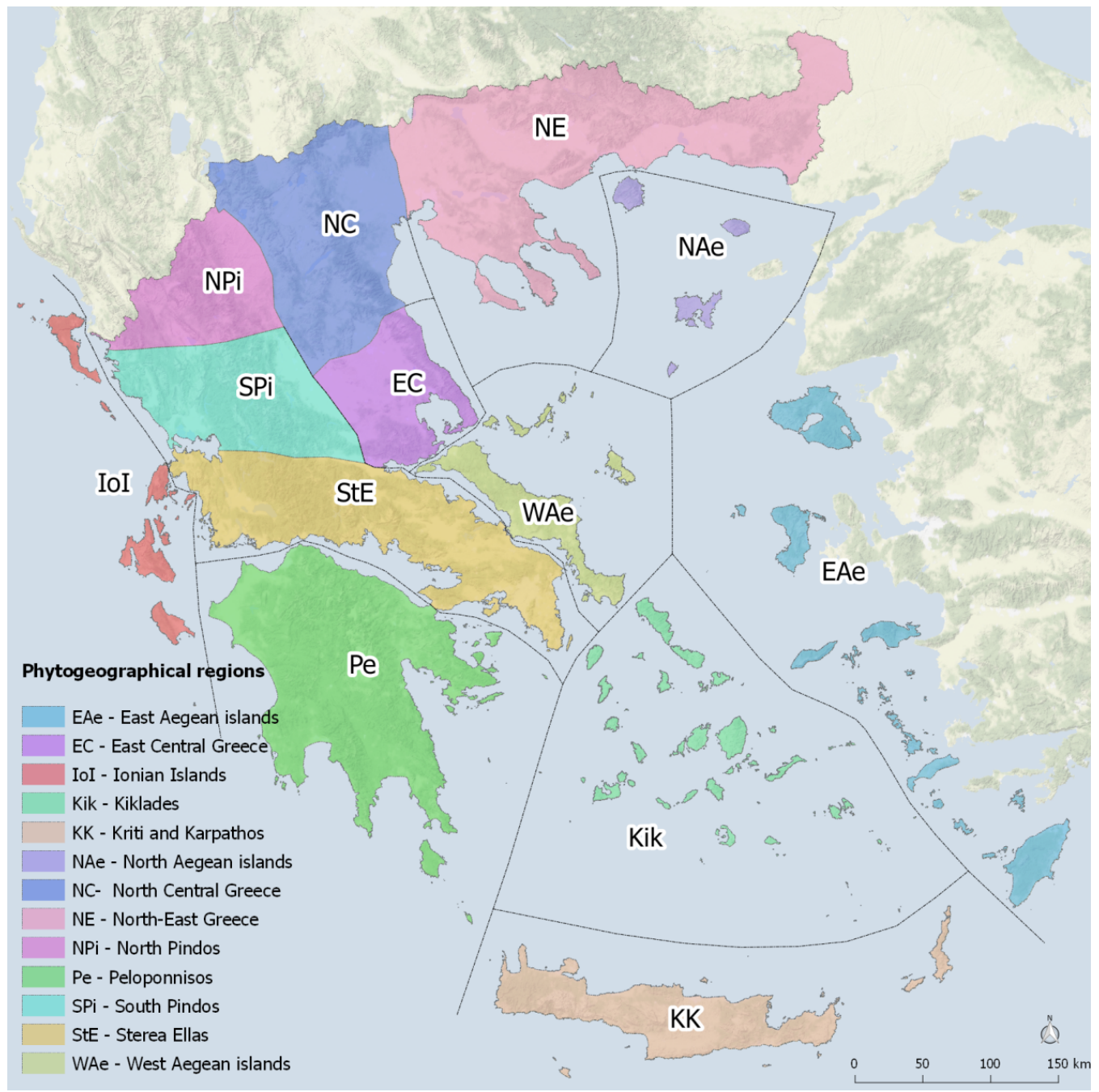

Figure 1 Phytogeographical regions of Greece according to Strid \& Tan (1997)

Background: Map tiles by Stamen Design, under CC BY 3.0

the chorological classification of taxa presented in Dimopoulos et al. (2013) and Dimopoulos et al. (2016). In addition to the chorological categories, we considered "range restricted taxa," which are taxa occupying a distribution area that does not exceed a linear distance of $500 \mathrm{~km}$. Unlike endemic taxa, these taxa might occur in more than one country (Dimopoulos et al. 2013).

\section{Grouping of phytogeographical regions}

Phytogeographical regions were grouped according to their similarity in floristic composition. A cluster analysis was performed using the Simpson's dissimilarity index (Lennon et al. 2001), as presented in Koleff et al. (2003) (dist. measure " $b_{\text {sim }}$ " in Table 1 in Koleff et al. 2003), and implemented in the $\mathrm{R}$ package "vegan" (Oksanen et al. 2017). This dissimi- 
larity measure was used because it focuses on compositional differences, not differences in richness (Koleff et al. 2003). Ward's method (Ward 1963) was used as the linkage method for clustering the phytogeographical regions. The analysis was performed for all taxonomic levels. The cophenetic correlation was used to assess the similarity between the classifications of the phytogeographical regions when different taxonomic levels were considered (Kassambara 2017). The analysis was performed using the "dendextend" package (Galili 2015) in $\mathrm{R}$. To test the significance, we permuted one of the two dendrograms 999 times using the function "sample.dendrogram" from R package "dendextend" (Galili 2015). We then tested the actual value of the statistic (cophenetic correlation in unpermuted trees) with the distribution of the values obtained from the permutations (cophenetic correlation in permuted trees). The analysis was performed using the R package "vegan" (Oksanen et al. 2017). At the species taxonomic level, non-metric multidimensional scaling (NMDS) was performed to order the phytogeographical regions in the species space. Parameters describing the chorological spectrum of each floristic region were post-hoc correlated with the coordinates of the phytogeographical regions along the ordination axes.

\section{$\beta$-diversity partitioning and gradients}

The analysis of $\beta$-diversity (i.e., the compositional variation of assemblages (Baselga 2010)) patterns was performed at three taxonomic levels: family, genus, and (sub-) species. For the species level, we included all woody species and subspecies (hereafter, when we refer to "species", subspecies are also included if no other specification is made). At the species level, the floristic inventory included the presence/absence of each species in each phytogeographical region. At the levels of "family" and "genus," the number of taxa in phytogeographical region was used. For the taxonomic levels of families and genera, the $\beta$-diversity assessment was also based on presence/absence indices. Moreover, to account for the effect of differences in the surface area of each phytogeographical region, the area-weighted richness for each taxonomic level was calculated by dividing the number of species (genera, families) with the surface area of each phytogeographical region. Finally, we estimated all the linear regression models between species richness and surface area of phytogeographical regions (both at logarithmic scale) for all life-forms (woody taxa, woody phanerophytes and woody chamaephytes) and for all chorological categories to test the hypothesized linear relationship between species richness and surface area in loglog space (Connor \& McCoy 1979).

At the species taxonomic level, for all phytogeographical regions, $\beta$-diversity was partitioned as turnover and nestedness (Baselga 2010). The analysis was performed using the R package "betapart" (Baselga \& Orme 2012), and the "Sørensen" index as a measure of total dissimilarity. To test whether the distances (dissimilarities expressed by estimating total $\beta$-diversity and its partitioned components) among the phytogeographical regions are correlated to the corresponding distances in geographic space, a Mantel correlation test was performed (Legendre et al. 2015) in the $\mathrm{R}$ package "vegan" (Oksanen et al. 2017). Geographic distances were estimated between the centroids of phytogeographical regions by using the software QGIS (QGIS Development Team 2017). The presence of floristic gradients in the dissimilarities of woody flora of Greece between phytogeographical regions was examined by estimating a series of Mantel directional correlation coefficients between the dissimilarities of the total and partitioned (turnover and nestedness) $\beta$-diversity and the dissimilarities in geographic space at regular direction intervals (Wildi 2017a). The analysis was performed using R package "dave" (Wildi 2017b) for the three taxonomic levels. 
The function 'dircor2' of the R package 'dave' was modified to accept any dissimilarity matrix derived from floristic data. At the species taxonomic level, dissimilarities in floristic composition were expressed as: total $\beta$-diversity, nestedness, and turnover (Baselga 2010). Dissimilarity at the taxonomic levels of genus and family were measured using 'Simpson's' dissimilarity index. The directional step was set to $5^{\circ}$.

\section{Results}

\section{Species composition and chorological spec- trum of the phytogeographical regions}

In total, 656 woody taxa that were classified into 214 genera and 85 families were identified from the flora of Greece. The distribution of the taxa at the three taxonomic levels in the phytogeographical regions is shown in Figure 2.

The phytogeographical region of NorthEast Greece (NE) has the highest number of woody species, followed by Sterea Ellas (StE) and Peloponnisos (Pe), all of which contained over 350 recorded woody species. The lowest number of species (194) was recorded in the Kiklades (Kik) phytogeographical region. Kriti-Karpathos (KK) hosted the highest number of endemic and range restricted woody species. Phanerophytes was the dominant lifeform in all phytogeographical regions, except for Kriti-Karpathos. At the genus level, Peloponnisos had the highest recorded number (171), followed by Sterea Ellas (169 genera). The same ordering was observed at the family level. This pattern changed when the area-weighted number of taxa was considered. The phytogeographical regions of North Aegean islands (NAe), Ionian islands (IoI), and Kriti \& Karpathos (KK) clearly had the highest values (Figure 2).

The chorological spectrum of the phytogeographical regions and the number of cha- maephytes and phanerophytes is shown in supplementary material 1 . The percentage (\%) contribution of the chorological categories to the chorological spectrum of the phytogeographical regions of Greece is shown in Figure 3.

Mediterranean species clearly dominate the chorological spectrum of all phytogeographical regions in Greece. In comparison, widespread species had a considerably high percentage in the northern phytogeographical regions (NC, NE and NPi), which decreased towards the southern phytogeographical regions. The phytogeographical regions of KK and $\mathrm{Pe}$ are characterized by high numbers of endemic and range restricted species. The phytogeographical regions with the highest relative proportion of chamaephytes were KK and Kik (supplementary material 1), i.e., the southernmost phytogeographical regions, while the regions with the lowest proportion were North Pindos and North Aegean islands.

The linear regression models between the log-transformed richness of the various chorological categories and life forms and the log-transformed surface area of the phytogeographical regions are shown in supplementary material 2 and 3. There was a significant linear relationship between total species richness and surface area, particularly when only Balkan and Mediterranean species were considered. The same significant models were observed when only phanerophytes or only chamaephytes were considered. There was just one exception, where a non-significant model was obtained between the species richness of all chamaephytes and surface area of phytogeographical regions. There was a negative, but non-significant, slope in the model of richness of alien chamaephytes and surface area of phytogeographical regions.

\section{Grouping of phytogeographical regions}

At the species taxonomic level and when all taxa were considered, three distinct groups 

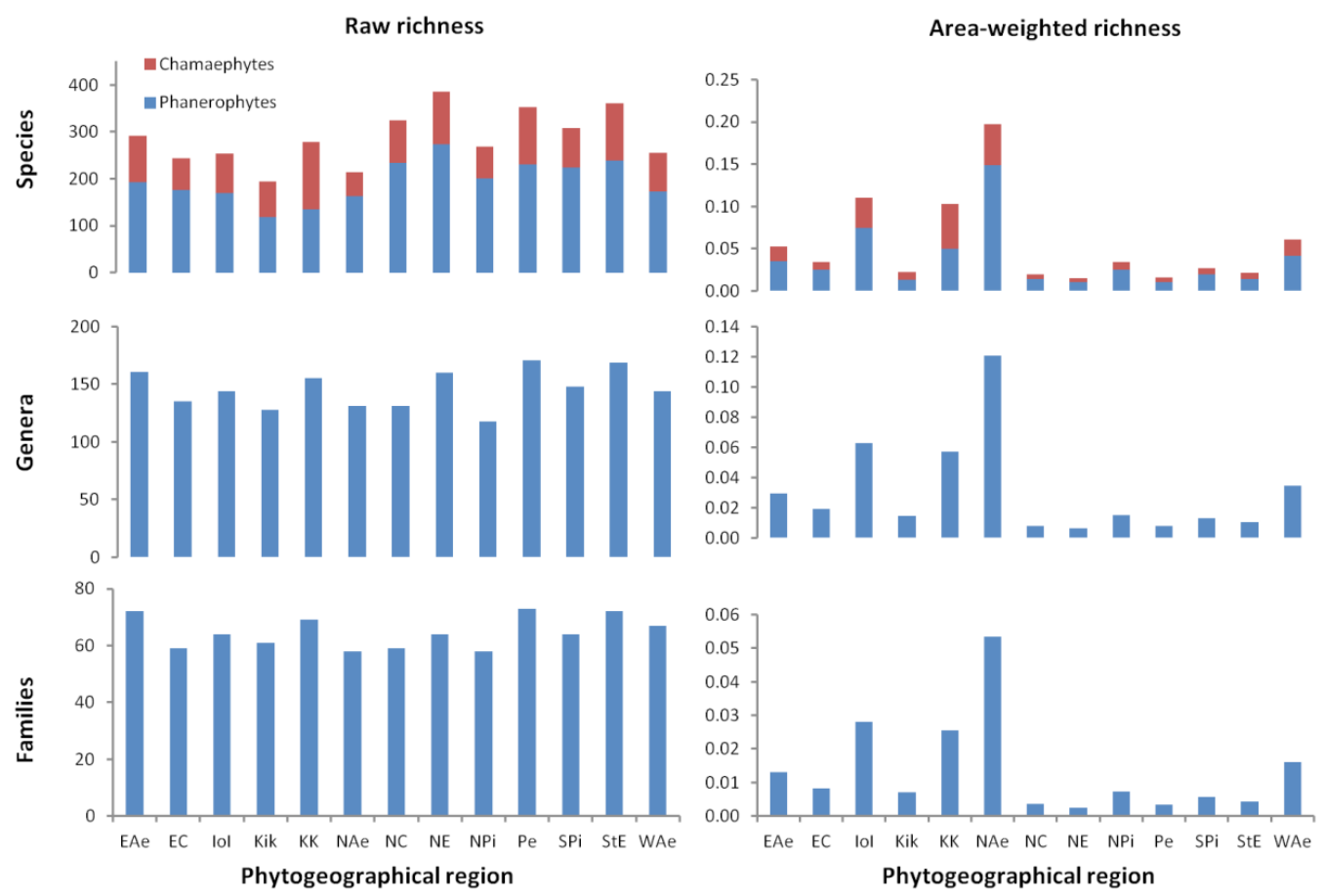

Figure 2 Raw (left) and Area-weighted (right) richness of woody vascular plants in the phytogeographical regions of Greece. See Fig. 1 for full terms of the abbreviations for the regions.

were identified from the cluster analysis (Figure 4).

The first group included all the northern and central phytogeographical regions $(\mathrm{NE}, \mathrm{NC}$, EC, NPi, SPi) of mainland Greece. The second group included central and southern mainland phytogeographical regions ( $\mathrm{Pe}, \mathrm{StE})$, as well as the islands of the Ionian Sea (IoI) and western (WAe) and northern Aegean Sea (NAe). The third group included the East Aegean islands (EAe), Kiklades (Kik), and Kriti \& Karpathos (KK). This grouping exhibited a characteristic north-west to south-east gradient, as shown in the embedded map in Figure 4. The floristic composition of the phytogeographical regions of Greece displayed most of its variation along a main gradient related to the number of widespread and Balkan endemic taxa. A secondary gradient that was related to Greek endemic taxa was apparent.

\section{$\beta$-diversity partitioning and gradient}

Beta diversity partitioning among adjacent phytogeographical regions is shown in Figure 5.

Turnover clearly dominated, but there were phytogeographical regions in which the nestedness component of $\beta$-diversity was higher (Table 1).

The phytogeographical region of KK had the highest species turnover, followed by the EAe and the IoI phytogeographical regions. Total dissimilarity (i.e., distance between phytogeographical regions in floristic space) increased with increasing geographic distance (Table 1). This increment was mostly based on the increase in turnover rates (i.e., change in floristic composition), rather than a change due to nestedness, the values of which were not significantly correlated with geographical 
$\%$ of taxa

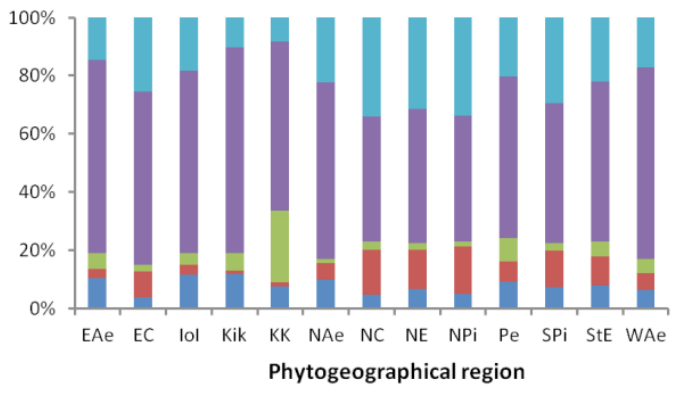

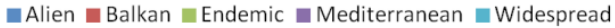

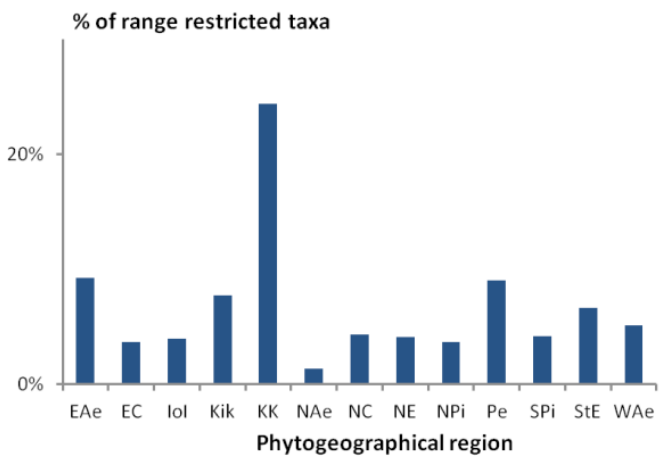

Figure 3 Chorological spectrum (top panel) and percentage of range-restricted species (bottom panel) of the 13 phytogeographical regions in Greece. See Fig. 1 for full terms of the abbreviations for the regions.

distance. The floristic composition of woody taxa among the phytogeographical regions at the species level had a distinct gradient, which was strongest along the direction of about $65^{\circ}$ (Figure 6). The same pattern was observed for the other two taxonomic levels, but there was a small shift in the direction of the strongest gradient for genera (Figure 6).

The gradient inferred in the directional correlogram corresponded to a North-West to South-East direction, further supporting the grouping of phytogeographical regions using the cluster analysis and ordination (Figure 4). At the species taxonomic level, turnover (Figure $6-$ a.1) showed a strong directional gradient, and determined the observed directional 8

\section{Table 1}

Mean turnover and nestedness among neighboring phytogeographical regions. Shaded cells indicate higher nestedness than turnover. Phytogeographical regions in parentheses are those that are directly adjacent to the region under consideration. Output of the Mantel correlation analysis between distance matrices in floristic space (turnover and nestedness of $\beta$-diversity and dissimilarity) and distance matrices in geographical space. *: correlation significant at 0.05 level; ** correlation significant at 0.01 level. See Fig. 1 for full terms of the abbreviations for the regions.

\begin{tabular}{lll}
\hline Region & $\begin{array}{l}\text { Mean } \\
\text { turnover }\end{array}$ & $\begin{array}{l}\text { Mean } \\
\text { nestedness }\end{array}$ \\
\hline $\begin{array}{l}\text { KK (Kik, Pe, } \\
\text { EAe) }\end{array}$ & 0.2935 & 0.079 \\
\hline $\begin{array}{l}\text { WAe (NAe, EAe, } \\
\text { Kik, StE, EC) }\end{array}$ & 0.2093 & 0.094 \\
\hline $\begin{array}{l}\text { Kik (EAe, KK, } \\
\text { Pe, WAe) }\end{array}$ & 0.1670 & 0.186 \\
\hline $\begin{array}{l}\text { NAe (EAe, } \\
\text { WAe, NE) }\end{array}$ & 0.1760 & 0.150 \\
\hline $\begin{array}{l}\text { StE (EC, WAe, } \\
\text { Pe, IoI, SPi) }\end{array}$ & 0.1309 & 0.134 \\
\hline $\begin{array}{l}\text { SPi (NC, EC, } \\
\text { StE, IoI, NPi) }\end{array}$ & 0.1926 & 0.062 \\
\hline $\begin{array}{l}\text { NC (NE, EC, } \\
\text { SPi, NPi) }\end{array}$ & 0.1454 & 0.075 \\
\hline $\begin{array}{l}\text { NE (NAe, } \\
\text { EC, NC) }\end{array}$ & 0.1115 & 0.179 \\
\hline $\begin{array}{l}\text { NPi (NC, } \\
\text { SPi, IoI) }\end{array}$ & 0.2238 & 0.053 \\
\hline $\begin{array}{l}\text { Pe (StE, Kik, } \\
\text { KK, IoI) }\end{array}$ & 0.1804 & 0.122 \\
\hline $\begin{array}{l}\text { EAe (KK, Kik, } \\
\text { WAe, NAe) }\end{array}$ & 0.2335 & 0.091 \\
\hline $\begin{array}{l}\text { EC (NE, WAe, } \\
\text { StE, SPi, NC) }\end{array}$ & 0.1597 & 0.123 \\
\hline $\begin{array}{l}\text { IoI (NE, EC, } \\
\text { SPi, NPi) }\end{array}$ & 0.2352 & 0.097 \\
\hline $\begin{array}{l}\text { Turnover } \\
\text { Nestedness } \\
\text { Total dissimilarity }\end{array}$ & $\begin{array}{l}\text { Mantel statistic } r: \\
0.6766^{* *}\end{array}$ \\
\hline \\
\hline
\end{tabular}



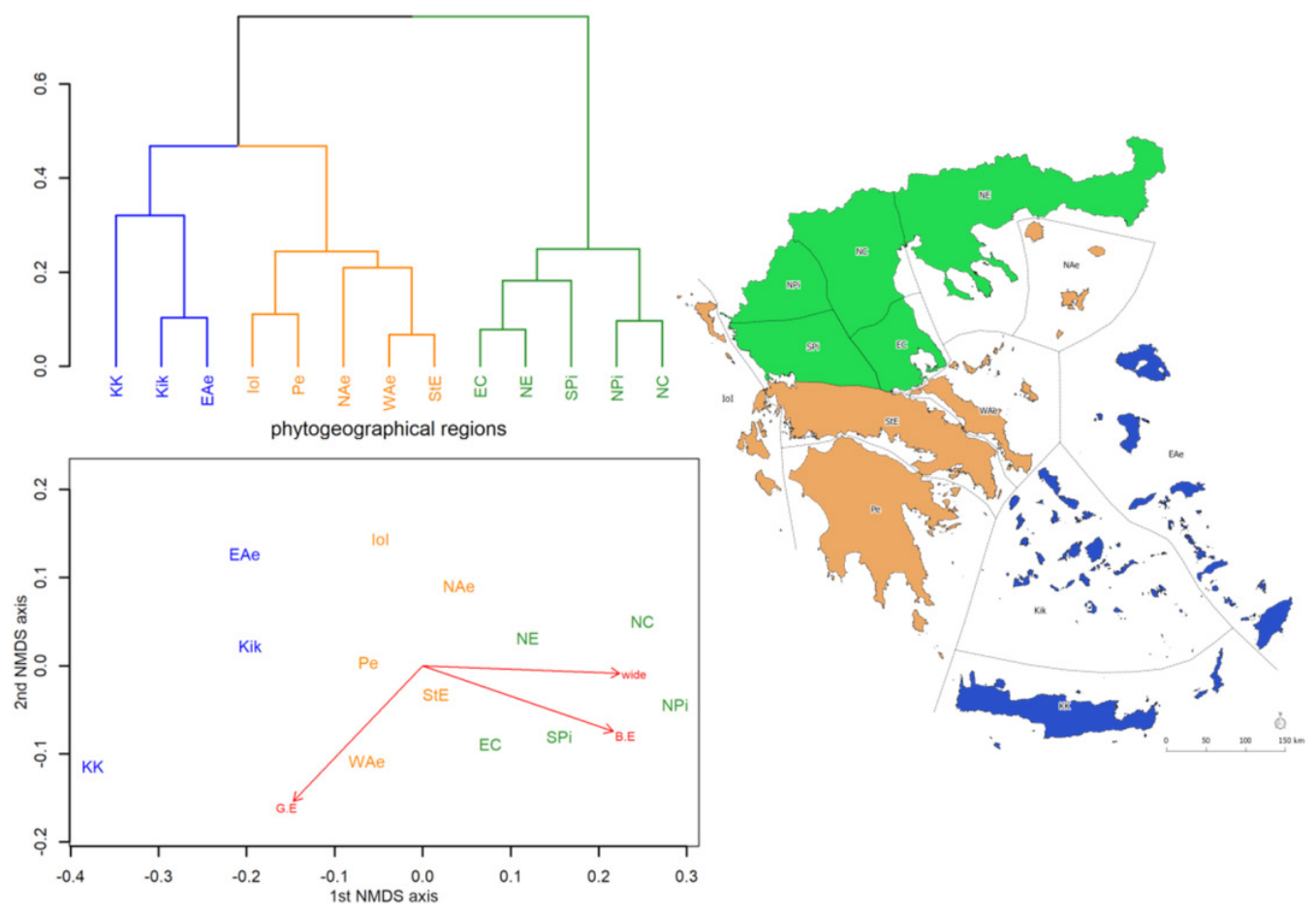

Figure 4 Dendrogram and NMDS ordination diagram of the phytogeographical regions. Abbreviations: B.E: Balkan Endemics; wide: widespread species; G.E.: Greek endemic species. See Fig. 1 for full terms of the abbreviations for the regions.

gradient of total $\beta$-diversity.

The outputs of the cluster analysis at the two higher taxonomic levels (genus and family) are shown in Figure 7. The differences between phytogeographical regions (expressed by the height [distance among clusters] of the cluster dendrogram) increased from family to genus to species level.

The phytogeographical regions were grouped in three distinct groups when species and genera were considered. However, just two groups were delineated when families were considered. Cluster membership and cluster distinction gradually changed across the three taxonomic levels. The group formed by the phytogeographical regions of KK, Kik, and EAe is one such example. At the taxonomic level of families and genera, this group was clearly distinguishable and separated at an early stage of the clustering procedure, indicating a distinct composition from all other phytogeographical regions. At the species taxonomic level, this group was identified as a sub-group that included the southernmost phytogeographical regions of the country. The highest cophenetic correlation coefficient was observed for the pairwise comparison of the cluster dendrograms when the taxonomic levels of families and genera are considered. The lowest cophenetic correlation coefficient showed no significant correlation when comparing the taxonomic level of families and species. The output of the pairwise Mantel correlation test (Figure 7) indicates a significant correlation between region clustering for all taxonomic levels. 


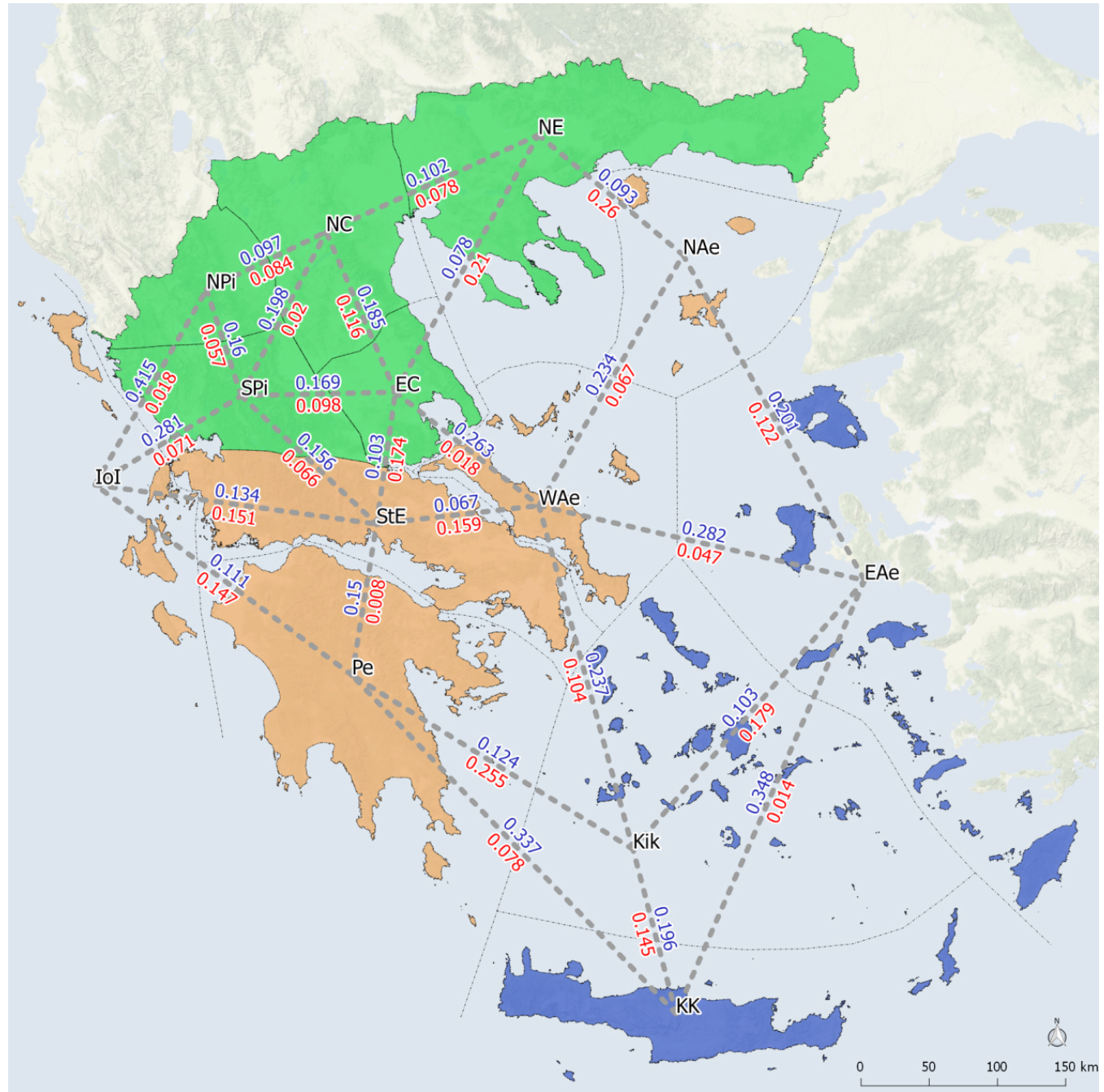

Figure 5 Beta diversity partitioning in turnover (values in blue ink) and nestedness (values in red ink) between adjacent phytogeographical regions. See Fig. 1 for full terms of the abbreviations for the regions.

\section{Discussion}

Greece contains more woody taxa (565 woody taxa) compared to Italy (509 woody taxa; Abbate et al. 2015) and Bulgaria (370 woody taxa; Yurukov \& Zhelev 2001). The chorological spectrum of woody species revealed clear similarities with other studies using complete floristic inventories at both national (Di10 mopoulos et al. 2013, Dimopoulos et al. 2016) and local scales (Chasapis et al. 2004, Spanou et al. 2006, Gouvas \& Theodoropoulos 2007, Sarika et al. 2015). A clear dominance of Mediterranean species was observed in all phytogeographical regions of Greece. Georghiou \& Delipetrou (2010) reported Peloponnisos, Kriti-Karpathos, and Sterea Ellas as the three phytogeographical regions hosting the larg- 

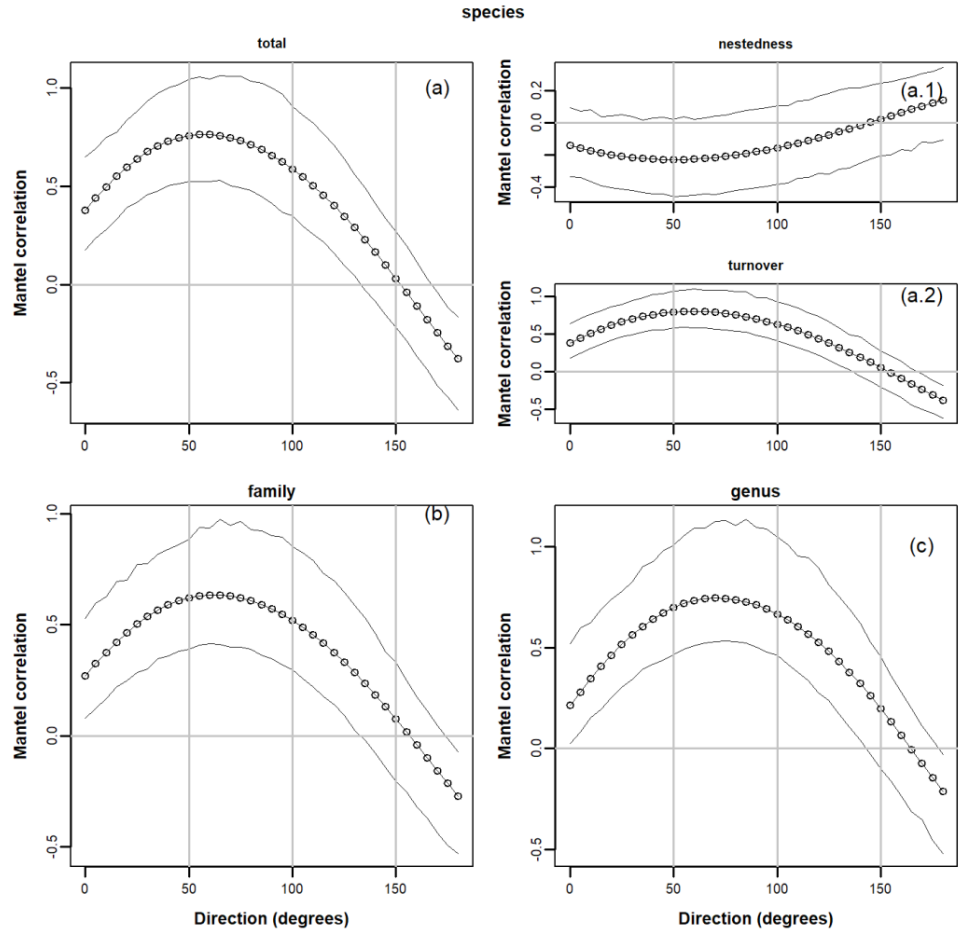

Figure 6 Mantel correlation between dissimilarities in floristic space and Euclidean distances in geographical space, evaluated in different directions. Dissimilarities in floristic composition are expressed as: total $\beta$-diversity at the taxonomic level of species (a); nestedness component of total $\beta$-diversity at the taxonomic level of species (a.1); turnover component of total $\beta$-diversity at the taxonomic level of species (a.2); dissimilarity at the family level (b) and dissimilarity at the genus level (c). The grey, solid lines represent the limits of the $95 \%$ envelopes.

est number of endemic vascular species. Dimopoulos et al. (2016) and Dimopoulos et al. (2013) reached the same conclusion; yet, when the number of range-restricted vascular taxa is considered, rather than of the number of endemic taxa, the phytogeographical regions of Peloponnisos, Sterea Ellas, and North Central Greece hold the top three ranks. Regarding the distribution of life forms, more woody chamaephytes were observed in the southern, more xeric phytogeographical regions of Greece, supporting studies in other parts of Mediterra- nean Europe (Terradas 1991). Chamaephytes are more adapted to arid environments than phanerophytes (Smith 1913).

The positive linear relationships between species richness and surface area in the loglog space were expected based on descriptions from previous works related to biogeography (Kallimanis et al. 2010, Triantis et al. 2015). The rate at which species richness accumulates with increased area (i.e., the model slope), showed considerable variability when the different chorological categories and life forms were evaluated. The observed deviations were partially explained by the small sample size (13 phytogeographical regions) and the small number of taxa used in the analyses. For example, the negative richness-area relationship of alien chamaephytes is probably attributed to the very small number (0-3) of these taxa in each phytogeographical region. Unfortunately, it was not possible to draw sound conclusions from the current data set, with further research being required.

The $\beta$-diversity of the woody flora of Greece was mostly expressed as compositional turnover, and was maximal along a north-west to south-east direction. Turnover is expected to be the dominant component of $\beta$-diversity (Calderón-Patrón et al. 2016, Janne et 


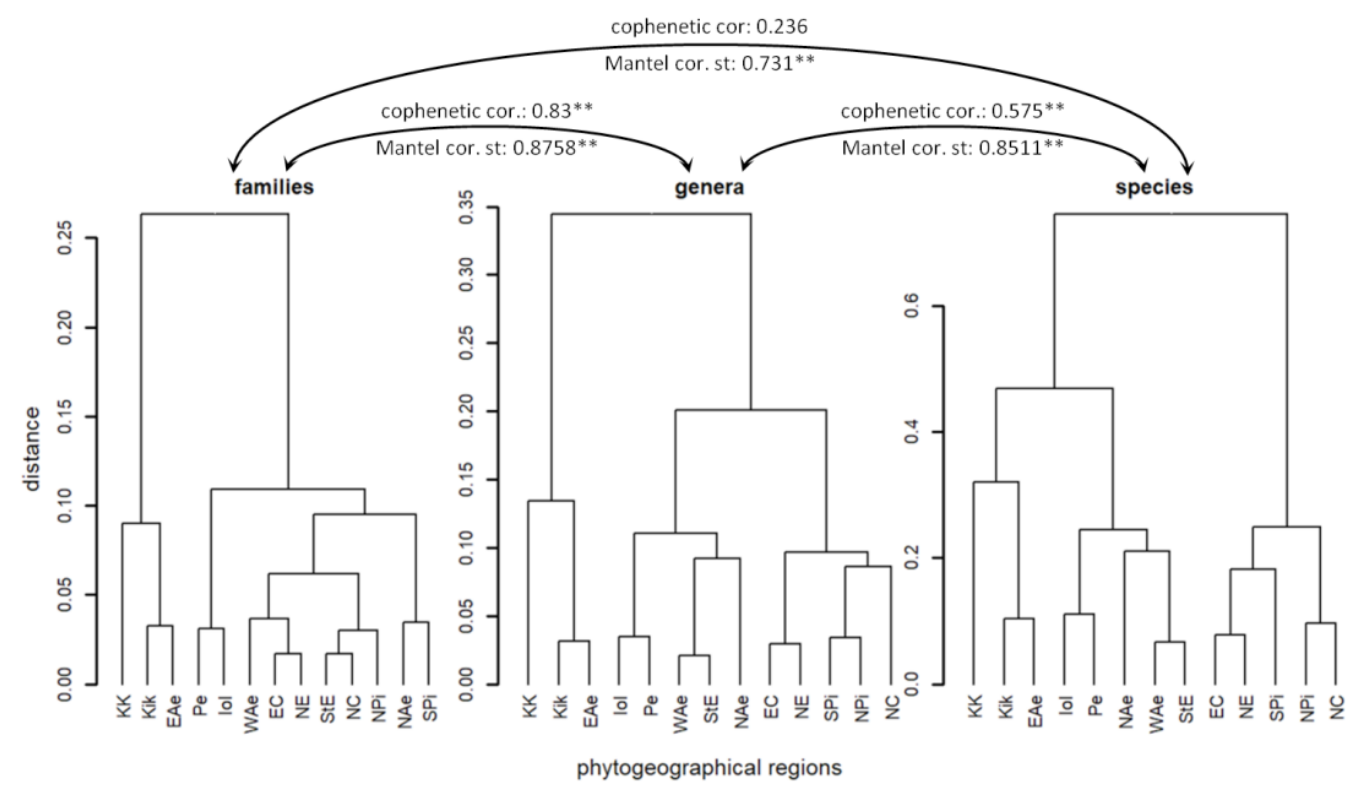

Figure 7 Dendrograms of phytogeographical regions based on dissimilarities between their woody taxa flora at the level of the family (left), genus (center), and species (right). Pairwise cophenetic correlations between dendrograms and Mantel correlations between dissimilarity matrices are also shown. * correlation significant at 0.05 level; ** correlation significant at 0.01 level. Abbreviations: cor. - correlation, st - statistic. See Fig. 1 for full terms of the abbreviations for the regions.

al. 2018), but the nestedness component in Kiklades, Sterea Ellas, and North-East Greece was larger than the turnover component. Latitudinal gradients are often observed in vegetation ecology, and beta diversity tends to be maximized along a north-south direction in various temperate regions of the world (Qian et al. 2005). One of the main factors shaping the observed latitudinal pattern in woody plant occurrence in Greece is the north-south temperature and precipitation cline of the region (Lolis et al. 1999, Gouvas et al. 2009). Changing climatic conditions from Mt Rhodope in northern Greece, which has a continental character with cool summers and cold winters, to southern regions with typical Mediterranean to almost sub-arid climate (Krina et al. 2017), induce obvious species turnover. A similar climate - driven differentiation among phytogeo- graphical regions induced by species turnover is also found in Australia (González-Orozco et al. 2014). One could argue that Greece does not actually have a long latitudinal extension; yet, this pattern was observed at both local and regional scales within broader climatic zones (Qian \& Ricklefs 2007, Abbate et al. 2012). A secondary west to east precipitation gradient divides Greece into a more maritime western part and a drier eastern part (Strid \& Tan 1997). The main watershed of Greece is the Pindos Mountain Chain, which extends to the Peloponnisos (Mt. Mainalo, Mt. Taygetos) and Crete (Lefka Ori). It was not possible to elucidate the possible effects of this east-west precipitation gradient in species turnover because all the phytogeographical regions that run along the main watershed include both windward and leeward sides. 
Several studies have suggested that physiographic and landscape variables, as well as disturbance regime, influence total vascular species richness (Whittaker et al. 2001, Panitsa et al. 2006, Qian \& Ricklefs 2007). Yet, it is safe to assume that floristic variation induced by such factors should be low between the various phytogeographical regions of Greece, because their spatial extent is sufficiently large enough to include a variety of parameters. For example, differences in land cover/use diversity (measured as Shannon's diversity index of the CORINE level 1 and 2 land use/cover classes) between phytogeographical regions are small and not significant (unpublished data). This limited variation allows us to exclude these parameters as possible causes for the observed pattern in $\beta$-diversity of woody species at the spatial scale adopted in this study. An exception could be the phytogeographical regions that consist of considerably small and low-elevation islands, like the Kiklades and the Ionian islands. In these regions, topographic variability is expected to be lower than in other phytogeographical regions of Greece; thus, species richness is typically lower ("Kykladenfenster" after Rechinger in Strid \& Tan 1997). Alternatively, isolation may also shape species diversity pattern on islands (or 'island areas' in the broadest sense) (Whittaker et al. 2001) and might counterbalance the effect of the lack of landscape variability. Islands can host relatively species-poor assemblages, but with a high number of endemic species (Field 2002). Speciation in the Aegean Archipelago, in which the Kiklades phytogeographical region is included, might explain the recorded high number of endemic taxa (Kallimanis et al. 2011). However, many species are shared between the Kiklades and adjacent phytogeographical regions (Strid \& Tan 1997). This is also valid for the woody flora, as indicated by the high rates of nestedness of woody taxa. Certainly, a more thorough biogeographical analysis of the flora of the Aegean islands is required, a task that has been already been advocated (Strid
2016).

The framework for the pattern of $\beta$-diversity also sets the basis for explaining the observed differences in the chorological spectrum between phytogeographical regions. The most important chorological gradient is the reduction of widespread taxa (sensu Dimopoulos et al. 2013) from the north to the south. Climatic variability in Greece follows a distinct north to south direction. The northern phytogeographical regions include transitional areas from the Mediterranean to more continental biogeographic zones (Bunce et al. 2002, Krina et al. 2017). This gradual climate cline towards typical Mediterranean, from northern to southern Greece, further explains the reduction of widespread woody species and the increase in Mediterranean woody species in the southern parts of the country. The exchange of floristic elements between adjacent phytogeographical regions, even those with different climates, is expected. For example, a large number of Mediterranean floristic elements are found in the lowland plains of southern Bulgaria (Yurukov \& Zhelev 2001). In comparison, central European and boreal species are expected to be present in the northern parts of the country, especially in areas that are characterized by a more continental climate type (Krina et al. 2017). Within a similar framework, the woody flora of Italy exhibits high affinity with primarily climatic factors (Abbate et al. 2012).

In addition to the obvious taxonomic and chorotypical affinities along the climatic gradient in Greece, paleogeographical aspects must be considered when explaining the observed pattern of floristic variation. The Balkan Peninsula acted as a glacial refuge for populations of northern taxa (Bennett et al. 1991, Médail \& Diadema 2009). Greek flora was affected by east-to-west or north-to-south migrations during different geological periods (Georghiou \& Delipetrou 2010). There is also strong evidence that north Greece hosts important refugial areas for many tree species or populations of northern or oriental origin, including 
beech (Magri 2008, Papageorgiou et al. 2008). Thus, historical plant migrations could partly explain the richness of widespread woody species in the northern phytogeographical regions. Woody taxa of northern or oriental origin could have radiated southwards through the mountainous chains, which, conditionally, act as bridges allowing the diffusion of species (Magri et al. 2006). Because this study only focused on woody species, it was not possible to distinguish the possible influence of oriental floristic elements in the chorological spectrum of the Greek phytogeographical regions. Like other neighboring countries (Yurukov \& Zhelev 2001), the Greek flora, particularly in East Aegean islands, has a strong affinity with Anatolian flora, when all species are examined (Strid \& Tan 1997). Yet this affinity is not distinct for woody flora, with the observed eastto-west floristic gradient being weak.

Our results show that using higher taxonomic levels in analyses of phytogeographical regions does not alter the qualitative nature of the outputs. The classification of phytogeographical regions was qualitatively identical at the taxonomic levels of species and genera, and only slightly different at the family level. Similarly, the highest dissimilarity in floristic composition was found along the north-west to south-east axis for all three taxonomic levels. Differences are expected to be less pronounced, due to the sequential aggregation of taxonomic units at higher levels. This phenomenon explains the decrease in $\beta$-diversity between regions when higher taxonomic levels are considered (Willig et al. 2003, Qian \& Ricklefs 2007). Existing studies show that the use of higher taxonomic levels noticeably reduces survey costs for many organisms, producing acceptable results when overall species richness is surrogated by richness in families (Williams \& Gaston 1994, Terlizzi et al. 2009); however, the current study supported only the use of genera (not families) as an adequate surrogate for the species taxonomic level.

\section{Limitations and prospects}

To quantify the (combined) effects of various parameters (topographic, land use/cover, climatic) shaping $\beta$-diversity patterns (Altamirano et al. 2010) robustly, thorough analysis is required. The large area covered by the phytogeographical regions could impede the observation of detailed spatial patterns in beta-diversity. This relationship could only be revealed by analyzing data (floristic and environmental) measured at a suitable resolution (Pausas \& Austin 2001). The relative importance of topography and climate change depends on the spatial scale, with topography increasing in importance at finer scales (Keil et al. 2012). Gridded data at moderate spatial resolutions (Field 2002) or data with more distinct and local geographical distribution (such as islands and mountains) should be used to draw reliable conclusions.

Knowledge of $\beta$-diversity patterns at a variety of taxonomic levels is important for conservation planning (Devictor et al. 2010). Areas with high turnover rates and low nestedness should be prioritized in planning schemes that aim to conserve diversity. However, this knowledge must be enriched with analyses of phylogenetic (Médail \& Baumel 2018) and trait diversity patterns to establish conservation priorities within a more comprehensive framework (Calderón-Patrón et al. 2016). Unfortunately, there is a lack of phylogenetic and trait information for many taxa (especially local endemics). Therefore, the analysis of patterns of $\beta$-diversity is mostly based on analyses of species compositional patterns.

\section{Acknowledgments}

The authors thank the two reviewers who significantly improved the original manuscript with their valuable comments and Gail Schofield for linguistic revisions of the manuscript. 


\section{References}

Abbate G., Bonacquisti S., Burrascano S., Giovi E., Giuliani A., Pretto F., Scassellati E., 2015. Woody flora as a predictor of vascular plant richness: An insight in Italy. Plant Biosystems - An International Journal Dealing with all Aspects of Plant Biology 149(3): 565-573.

Abbate G., Iberite M., Bonacquisti S., Giovi E., Iamonico D., Scassellati E., 2012. Taxonomical and chorological diversity of native woody flora of Italy at regional scale. Bocconea 24: 169-175.

Altamirano A., Field R., Cayuela L., Aplin P., Lara A., Rey-Benayas J.M., 2010. Woody species diversity in temperate Andean forests: The need for new conservation strategies. Biological Conservation 143(9): 20802091. DOI: 10.1016/j.biocon.2010.05.016

Bannister J.R., Vidal O.J., Teneb E., Sandoval V., 2012. Latitudinal patterns and regionalization of plant diversity along a 4270-km gradient in continental Chile. Austral Ecology 37(4): 500-509. DOI: 10.1111/j.14429993.2011.02312.x

Baselga A., 2010. Partitioning the turnover and nestedness components of beta diversity. Global Ecology and Biogeography 19(1): 134-143. DOI: 10.1111/j.14668238.2009.00490.x

Baselga A., Orme C.D.L., 2012. betapart: an R package for the study of beta diversity. Methods in Ecology and Evolution 3(5): 808-812. DOI: 10.1111/j.2041210X.2012.00224.X

Bennett K.D., Tzedakis P.C., Willis K.J., 1991. Quaternary refugia of North European trees. Journal of Biogeography $18(1): 103-115$. DOI: $10.2307 / 2845248$

Buckley L.B., Jetz W., 2008. Linking global turnover of species and environments. Proceedings of the National Academy of Sciences 105(46): 17836-17841. DOI: 10.1073/pnas.0803524105

Bunce R.G.H., Carey P.D., Elena-Rossello R., Orr J., Watkins J., Fuller R., 2002. A comparison of different biogeographical classifications of Europe, Great Britain and Spain. Journal of Environmental Management 65(2): 121-134. DOI: 10.1006/jema.2002.0533

Calderón-Patrón J.M., Goyenechea I., Ortiz-Pulido R., Castillo-Cerón J., Manriquez N., Ramírez-Bautista A., Rojas-Martínez A.E., Sánchez-Rojas G., Zuria I., Moreno C.E., 2016. Beta diversity in a highly heterogeneous area: Disentangling species and taxonomic dissimilarity for terrestrial vertebrates. PLOS ONE 11(8): e0160438. DOI: 10.1371 /journal.pone.0160438

Chasapis M., Karagiannakidou V., Theodoropoulos K., 2004. Phytosociological research of Quercus coccifera L. pseudomaquis on Mount Chortiatis, northern Greece. Israel Journal of Plant Sciences 52: 357-381. DOI: 10.1560/N0YU-G77C-TLKX-HW5K

Connor E.F., McCoy E.D., 1979. The Statistics and biology of the species-area relationship. The American Naturalist 113(6): 791-833. DOI: 10.1086/283438

Cowling R.M., Rundel P.W. Lamont B.B., Arroyo M.K., Arianoutsou M., 1996. Plant diversity in Mediterra- nean-climate regions. Trends in Ecology \& Evolution 11(9): 362-366. DOI: 10.1016/0169-5347(96)10044-6

Davis P.H., 1965-2000. Flora of Turkey and the East Aegean islands. Edinburgh.

Devictor V., Mouillot D., Meynard C., Jiguet F., Thuiller W., Mouquet N., 2010. Spatial mismatch and congruence between taxonomic, phylogenetic and functional diversity: the need for integrative conservation strategies in a changing world. Ecology Letters 13(8): 10301040. DOI: 10.1111/j.1461-0248.2010.01493.x

Dimopoulos P., Raus T., Bergmeier E., Constantinidis T., Iatrou G., Kokkini S., Strid A., Tzanoudakis D., 2013. Vascular plants of Greece: An annotated checklist. Berlin: Botanischer Garten und Botanisches Museum Berlin-Dahlem. Athens: Hellenic Botanical Society [Engletera 31], 372 p.

Dimopoulos P., Raus T., Bergmeier E., Constantinidis T., Iatrou G., Kokkini S., Strid A., Tzanoudakis D., 2016. Vascular plants of Greece: An annotated checklist. Supplement. Willdenowia 46(3): 301-347. DOI: 10.3372/ wi.46.46303

Field R., 2002. Latitudinal diversity gradients. Encyclopedia of life sciences. Macmillan Publishers Ltd, pp. 1-8. DOI: 10.1038/npg.els.0003233

Galili T., 2015. dendextend: an R package for visualizing, adjusting and comparing trees of hierarchical clustering. Bioinformatics 31(22): 3718-3720. DOI: 10.1093/ bioinformatics/btv 428

Georghiou K., Delipetrou P., 2010. Patterns and traits of the endemic plants of Greece. Botanical Journal of the Linnean Society 162(2): 130-422. DOI: $10.1111 /$ j.10958339.2010.01025.x

Gillman L.N., Wright S.D., Cusens J., McBride P.D., Malhi Y., Whittaker R.J., 2015. Latitude, productivity and species richness. Global Ecology and Biogeography 24(1): 107-117. DOI: 10.1111/geb.12245

Glavac V., 1996. Vegetationsökologie - Grundfragen, Aufgaben, Methoden [Vegetation ecology - Basic questions, lessons, methods]. Gustav Fischer, Jena, 358 p.

González-Orozco C.E., Ebach M.C., Laffan S., Thornhill A.H., Knerr N.J., Schmidt-Lebuhn A.N., Cargill C.C., Clements M., Nagalingum N.S., Mishler B.D., Miller J.T., 2014. Quantifying phytogeographical regions of Australia using geospatial turnover in species composition. PLOS ONE 9(3): e92558. DOI: 10.1371/journal. pone. 0092558

Gouvas M., Sakellariou N., Xystrakis F., 2009. The relationship between altitude of meteorological stations and average monthly and annual precipitation. Studia Geophysica et Geodaetica 53(4): 557-570. DOI: 10.1007/ s11200-009-0039-1

Gouvas M., Theodoropoulos K., 2007. Life-form and chorological spectra of the vegetation units of Mount Hymettus (C. Greece). Journal of Biological Research-Thessaloniki 8: 177-187.

Hillebrand H., 2004. On the generality of the latitudinal diversity gradient. The American Naturalist 163(2): 192-211. DOI: $10.1086 / 381004$ 
Jahn R., Schönfelder P., 1995. Exkursionflora für Kreta [Excursion flora for Crete]. Ulmer, Stuttgart, 446 p.

Janne S., Jani H., Jianjun W., 2018. A meta-analysis of nestedness and turnover components of beta diversity across organisms and ecosystems. Global Ecology and Biogeography 27(1): 96-109. DOI: 10.1111/geb.12660

Kallimanis A.S., Bergmeier E., Panitsa M., Georghiou K., Delipetrou P., Dimopoulos P., 2010. Biogeographical determinants for total and endemic species richness in a continental archipelago. Biodiversity and Conservation 19(5): 1225-1235. DOI: 10.1007/s10531-009-9748-6

Kallimanis A.S., Panitsa M., Bergmeier E., Dimopoulos P., 2011. Examining the relationship between total species richness and single island palaeo- and neo-endemics. Acta Oecologica 37(2): 65-70. DOI: 10.1016/j. actao.2010.11.008

Kassambara A., 2017. Practical guide to cluster analysis in R. CreateSpace, North Charleston, SC, USA, 187 p.

Keil P., Schweiger O., Kühn I., Kunin W.E., Kuussaari M., Settele J., Henle K., Brotons L., Pe'er G., Lengyel S., Moustakas A., Steinicke H., Storch D., 2012. Patterns of beta diversity in Europe: the role of climate, land cover and distance across scales. Journal of Biogeography 39(8): 1473-1486. DOI: 10.1111/j.13652699.2012.02701.x

Kobayashi Y., Koike F., 2010. Separating the effects of land-use history and topography on the distribution of woody plant populations in a traditional rural landscape in Japan. Landscape and Urban Planning 95(1): 34-45. DOI: 10.1016/j.landurbplan.2009.11.003

Koleff P., Gaston K.J., Lennon J.J., 2003. Measuring beta diversity for presence-absence data. Journal of Animal Ecology 72(3): 367-382. DOI: 10.1046/j.13652656.2003.00710.x

Kougioumoutzis K., Simaiakis S.M., Tiniakou A., 2014. Network biogeographical analysis of the central Aegean archipelago. Journal of Biogeography 41(10): 18481858. DOI: $10.1111 /$ jbi.12342

Kougioumoutzis K., Valli A.T., Georgopoulou E., Simaiakis S.M., Triantis K.A., Trigas P., 2017. Network biogeography of a complex island system: the Aegean Archipelago revisited. Journal of Biogeography 44(3): 651-660. DOI: 10.1111/jbi.12920

Kraft N.J.B., Comita L.S., Chase J.M., Sanders N.J., Swenson N.G., Crist T.O., Stegen J.C., Vellend M., Boyle B., Anderson M.J., Cornell H.V., Davies K.F., Freestone A.L., Inouye B.D., Harrison S.P., Myers J.A., 2011. Disentangling the drivers of $\beta$ diversity along latitudinal and elevational gradients. Science 333(6050): $1755-$ 1758. DOI: $10.1126 /$ science. 1208584

Kreft H., Jetz W., 2010. A framework for delineating biogeographical regions based on species distributions. Journal of Biogeography 37(11): 2029-2053. DOI: 10.1111/j.1365-2699.2010.02375.x

Krina A., Koutsias N., Pleniou M., Xystrakis E., 2017. Climatic classification of Greece: Update - Future estimation - relation with forest vegetation. 18th Congress of Hellenic Forestry Society \& International Workshop.
Hellenic Forestry Society Edessa, pp. 1088-1095.

Landeiro V.L., Bini L.M., Costa F.R.C., Franklin E., Nogueira A., de Souza J.L.P., Moraes J., Magnusson W.E., 2012. How far can we go in simplifying biomonitoring assessments? An integrated analysis of taxonomic surrogacy, taxonomic sufficiency and numerical resolution in a megadiverse region. Ecological Indicators 23: 366-373. DOI: 10.1016/j.ecolind.2012.04.023

Latini M., Bartolucci F., Conti F., Iberite M., Nicolella G., Scoppola A., Abbate G., 2017. Detecting phytogeographic units based on native woody flora: A case study in central peninsular Italy. The Botanical Review 83(3): 253-281. DOI: 10.1007/s12229-017-9185-2

Legendre P., Borcard D., Peres-Neto P.R., 2005. Analyzing beta diversity: Partitioning the spatial variation of community composition data. Ecological Monographs 75(4): 435-450. DOI: 10.1890/05-0549

Legendre P., Fortin M.-J., Borcard D., 2015. Should the Mantel test be used in spatial analysis? Methods in Ecology and Evolution 6(11): 1239-1247. DOI: 10.1111/2041-210X.12425

Lennon J.J., Koleff P., Greenwood J.J.D., Gaston K.J., 2001. The geographical structure of British bird distributions: diversity, spatial turnover and scale. Journal of Animal Ecology 70(6): 966-979. DOI: 10.1046/j.00218790.2001.00563.x

Lolis C.J., Bartzokas A., Metaxas D.A., 1999. Spatial covariability of the climatic parameters in the Greek area. International Journal of Climatology $19(2)$ : $185-196$. DOI: $10.1002 /($ SICI)10970088(199902)19:2<185::AID-JOC339>3.0.CO;2-0

Magri D., 2008. Patterns of post-glacial spread and the extent of glacial refugia of European beech (Fagus sylvatica). Journal of Biogeography 35(3): 450-463. DOI: 10.1111/j.1365-2699.2007.01803.x

Magri D., Vendramin G.G., Comps B., Dupanloup I., Geburek T., Gömöry D., Latałowa M., Litt T., Paule L., Roure J.M., Tantau I., van der Knaap W.O., Petit R.J., de Beaulieu J.-L., 2006. A new scenario for the Quaternary history of European beech populations: palaeobotanical evidence and genetic consequences. New Phytologist 171(1): 199-221. DOI: 10.1111/j.14698137.2006.01740.x

Médail F., Baumel A., 2018. Using phylogeography to define conservation priorities: The case of narrow endemic plants in the Mediterranean Basin hotspot. Biological Conservation 224: 258-266. DOI: $10.1016 /$ j. biocon.2018.05.028

Médail F., Diadema K., 2009. Glacial refugia influence plant diversity patterns in the Mediterranean Basin. Journal of Biogeography 36(7): 1333-1345. DOI: 10.1111/j.1365-2699.2008.02051.x

Mittelbach G.G., Schemske D.W., Cornell H.V., Allen A.P., Brown J.M., Bush M.B., Harrison S.P., Hurlbert A.H., Knowlton N., Lessios H.A., McCain C.M., McCune A.R., McDade L.A., McPeek M.A., Near T.J., Price T.D., Ricklefs R.E., Roy K., Sax D.F., Schluter D., Sobel J.M., Turelli M., 2007. Evolution and the lat- 
itudinal diversity gradient: speciation, extinction and biogeography. Ecology Letters 10(4): 315-331. DOI: 10.1111/j.1461-0248.2007.01020.x

O'Brien E.M., 1993. Climatic gradients in woody plant species richness: Towards an explanation based on an analysis of Southern Africa's woody flora. Journal of Biogeography 20(2): 181-198. DOI: 10.2307/2845670

Oksanen J., Blanchet F.G., Friendly M., Kindt R., Legendre P., McGlinn D., Minchin P.R., O'Hara R.B., Simpson G.L., Solymos P., Stevens M.H.H., Szoecs E., Wagner H., 2017. vegan: Community Ecology Package.

Panitsa M., Kontopanou A., 2017. Diversity of chasmophytes in the vascular flora of Greece: floristic analysis and phytogeographical patterns. Botanica Serbica 41(2): 199-211.

Panitsa M., Tzanoudakis D., Triantis K.A., Sfenthourakis S., 2006. Patterns of species richness on very small islands: the plants of the Aegean archipelago. Journal of Biogeography 33(7): 1223-1234. DOI: 10.1111/j.13652699.2006.01481.x

Papageorgiou A.C., Vidalis A., Gailing O., Tsiripidis I., Hatziskakis S., Boutsios S., Galatsidas S., Finkeldey R., 2008. Genetic variation of beech (Fagus sylvatica L.) in Rodopi (N.E. Greece). European Journal of Forest Research 127(1): 81-88. DOI: 10.1007/s10342-0070185-3

Pausas J.G., Austin M.P., 2001. Patterns of plant species richness in relation to different environments: an appraisal. Journal of Vegetation Science 12(2): 153-166. DOI: $10.2307 / 3236601$

Pignatti S, 1982. Flora d'Italia [Flora of Italy]. Vol I-III. Bologna.

QGIS Development Team, 2017. QGIS Geographic Information System. Open Source Geospatial Foundation.

Qian H., 2013. Environmental Determinants of Woody Plant Diversity at a Regional Scale in China. PLOS ONE 8(9): e75832. DOI: 10.1371/journal.pone.0075832

Qian H., Ricklefs R.E., 2007. A latitudinal gradient in large-scale beta diversity for vascular plants in North America. Ecology Letters 10(8): 737-744. DOI: 10.1111/j.1461-0248.2007.01066.x

Qian H., Ricklefs R.E., White P.S., 2005. Beta diversity of angiosperms in temperate floras of eastern Asia and eastern North America. Ecology Letters 8(1): 15-22. DOI: 10.1111/j.1461-0248.2004.00682.x

Qian Y., Wu Z., Zhao R., Zhang L., 2008. Vegetation patterns and species-environment relationships in the Gurbantunggut Desert of China. Journal of Geographical Sciences 18(4): 400-414. DOI: 10.1007/s11442-0080400-2

Roma-Marzio F., Bedini G., Peruzzi L., 2015. Updating the woody flora of Tuscany: the first comprehensive survey, two centuries after Savi's work. $110^{\circ}$ Congresso della Società Botanica Italiana - $\mathrm{II}^{\circ}$ International Plant Science Conference (IPSC) "Not only food: sustainable development, agro-biodiversity conservation \& human well being", Pavia, p. 153.

Sarika M., Bazos I., Zervou S., Christopoulou A., 2015.
Flora and vegetation of the European-network "Natura 2000" habitats of Naxos island (GR4220014) and of nearby islets Mikres Kyklades (GR4220013), Central Aegean (Greece). Plant Sociology 52(2): 3-56.

Smith W.G., 1913. Raunkiaer's "life-forms" and statistical methods. Journal of Ecology 1(1): 16-26. DOI: $10.2307 / 2255456$

Socolar J.B., Gilroy J.J., Kunin W.E., Edwards D.P., 2016. How Should Beta-Diversity Inform Biodiversity Conservation? Trends in Ecology \& Evolution 31(1): 67-80. DOI: $10.1016 /$ j.tree.2015.11.005

Soininen J., 2010. Species turnover along abiotic and biotic gradients: Patterns in space equal patterns in time? BioScience 60(6): 433-439. DOI: 10.1525/ bio.2010.60.6.7

Spanou S., Verroios G., Dimitrellos G., Tiniakou A., Georgiadis T., 2006. Notes on flora and vegetation of the sand dunes of Western Greece. Willdenowia 36(1): 235-246. DOI: 10.3372/wi.36.36119

Strid A., 2016. Atlas of the Aegean Flora-Part 1: Text \& Plates. Botanic Garden and Botanical Museum Berlin, Berlin, $700 \mathrm{p}$.

Strid A., Tan K., 1997. Flora Hellenica. Koeltz Scientific Books, Königstein, 547 p.

Strid A., Tan K., 2002. Flora Hellenica. A. R. G. Gartner. Verlag. K.G. Ruggell, 511 p.

Strid A., 1986. Mountain Flora of Greece. Cambridge University Press, Cambridge, $822 \mathrm{p}$.

Terlizzi A., Anderson M.J., Bevilacqua S., Fraschetti S., Włodarska-Kowalczuk M., Ellingsen K.E., 2009. Beta diversity and taxonomic sufficiency: Do higher-level taxa reflect heterogeneity in species composition? Diversity and Distributions 15(3): 450-458. DOI: 10.1111/j.1472-4642.2008.00551.x

Terradas J., 1991. Mediterranean woody plant growthforms, biomass and production in the eastern part of the Iberian Peninsula. In: Ros J.D., Prat N. (Eds.), Homage to Ramon Margalef or why is there such pleasure in studying nature (Oecologia aquatica; 10), Universitat de Barcelona, Barcelona, pp. 337-349.

Triantis K.A., Economo E.P., Guilhaumon F., Ricklefs R.E., 2015. Diversity regulation at macro-scales: species richness on oceanic archipelagos. Global Ecology and Biogeography 24(5): 594-605. DOI: 10.1111/ geb. 12301

Tutin T.G., Burges N.A., Charter A.O., Edmondson J.R., Heywood V.H., Moore D.M., Valentine D.H., Walters S.M., Webb D.A. (eds), 1993. Flora Europaea I. Cambridge University Press, Cambridge

Tutin T.G., Heywood V.H., Burges N.A., Moore D.M., Valentine D.H., Walters S.M., Webb D.A. (eds), 19681980. Flora Europaea II-IV. Cambridge University Press, Cambridge

Ward J.H., 1963. Hierarchical grouping to optimize an objective function. Journal of the American Statistical Association 58(301): 236-244. DOI: 10.1080/01621459.1963.10500845

Whittaker R.J., Willis K.J., Field R., 2001. Scale and spe- 
cies richness: towards a general, hierarchical theory of species diversity. Journal of Biogeography 28(4): 453470. DOI: 10.1046/j.1365-2699.2001.00563.x

Wildi O., 2017a. Data analysis in vegetation ecology. Wiley-Blackwell, 210 p. DOI: 10.1079/9781786394224.0000

Wildi O., 2017b. dave: Functions for "Data Analysis in Vegetation Ecology".

Williams P.H., Gaston K.J., 1994. Measuring more of biodiversity: Can higher-taxon richness predict wholesale species richness? Biological Conservation 67(3): 211217. DOI: 10.1016/0006-3207(94)90612-2

Willig M.R., Kaufman D.M., Stevens R.D., 2003. Latitudinal gradients of biodiversity: Pattern, process, scale, and synthesis. Annual Review of Ecology, Evolution, and Systematics 34(1): 273-309. DOI: 10.1146/annurev.ecolsys.34.012103.144032

Yurukov S., Zhelev P., 2001. The woody flora of Bulgaria: A review. Schweizerische Zeitschrift fur Forstwesen 152: 52-60. DOI: 10.3188/szf.2001.0052

Zhang M.-G., Slik J.W.F., Ma K.-P., 2016. Using species distribution modeling to delineate the botanical richness patterns and phytogeographical regions of China. Scientific Reports 6: 22400. DOI: 10.1038/srep22400

\section{Supporting Information}

The online version of the article includes Supporting Information:

Table S1. Surface area, chorological spectrum, and life-forms of the phytogeographical regions of Greece

Table S2. Linear regression models between species richness and surface area of phytogeographical regions in log-log space for all life forms and chorological categories

Fig. S1. Scatter-plots showing species richness vs surface area of phytogeographical regions for all life forms and chorological categories of the woody flora in Greece 